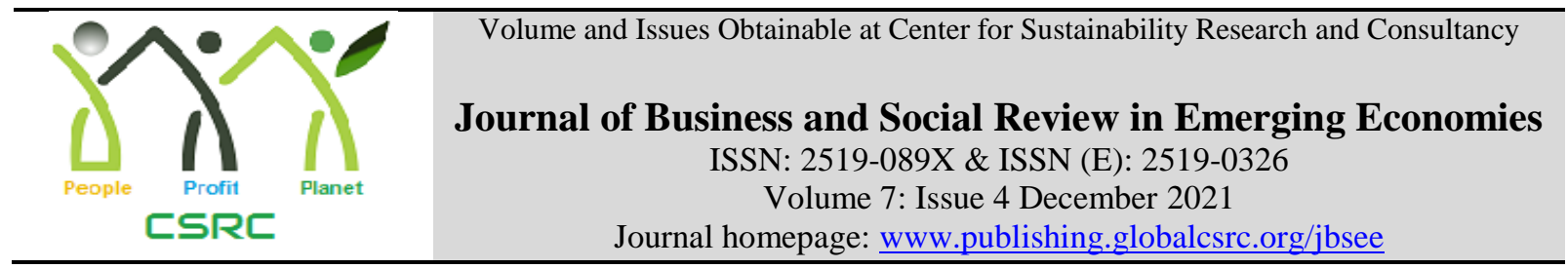

\title{
Fiscal Decentralization and Gender Parity in Education: Empirical Evidence from Pakistan
}

Sidra Naeem, Department of Economics, The Islamia University Bahawalpur, Pakistan Mahnaz Muhammad Ali, Department of Economics, The Islamia University Bahawalpur, Pakistan

*Hafeez ur Rehman, Department of Economics, The Islamia University Bahawalpur, Pakistan

*Corresponding author's email: hafeez.rehman@iub.edu.pk

\begin{tabular}{l}
\hline ARTICLE DETAILS \\
\hline History \\
Revised format: Nov 2021 \\
Available Online: Dec 2021
\end{tabular}

Keywords

Fiscal federalism, Gender parity in education, ARDL bounds test, Pakistan

JEL Classification H3O, E62, I24

\section{open ACCESS}

\section{ABSTRACT}

Purpose: Fiscal decentralization is an emerging phenomenon in Pakistan from the last few decades. A large number of studies have been investigated the socio-economic and political effects of fiscal decentralization in Pakistan. But none of the study has examined that how fiscal decentralization has affected gender parity in education in Pakistan.

Design/Methodology/Approach: This study empirically investigated the dynamic relationship between fiscal decentralization and gender equality in education by employing different measures of fiscal decentralization and used autoregressive distributed lag model (ARDL) bounds test approach for cointegration testing for the period of 1975 to 2020 . The bounds tests suggest that the variables of interest are bound together in the long run when gender parity in education is dependent variable.

Findings: The long run relationship is also confirmed by the significance of associated equilibrium correction. The robust analysis of this study suggest that fiscal decentralization is improving gender equality in education particularly education expenditure decentralization and revenue decentralization.

Implications/Originality/Value: The results are important for fiscal policy formulation in public and social sector in Pakistan. Further, these results might be helpful for other developing countries that share a common experience in applying fiscal decentralization reforms and struggling to reduce gender disparity in education sector.

(C) 2021 The authors, under a Creative Commons AttributionNonCommercial 4.0

Recommended citation: Naeem, S., Ali, m. M. and Rehman, H. (2021). Fiscal Decentralization and Gender Parity in Education: Empirical Evidence from Pakistan. Journal of Business and Social Review in Emerging Economies, 7 (4), 949-962. 


\section{Introduction}

Fiscal decentralization is considered a vital policy tool to distribute the resources effectively and it also ensure an efficient government as provinces have more financial autonomy. The smaller units of federation ${ }^{1}$ have more opportunities concentrate on their economic development and central government can complete the national level responsibilities efficiently. Accountability and efficiency are important rationales behind fiscal decentralization. Accountability of small organizations is easy comparatively to large organizations. Desires of citizens and provision of public goods are closely matched in decentralization which increase productivity and efficiency gains (Oates, 1972). Provincial government has informational advantage over the central government regarding resource distribution so more efficiency is expected. These informational benefits allow the provincial government to deliver public goods and services at preferences basis and at lower cost to local community. These efficiency benefits, dynamic or static, lead to advanced and more sustainable economic growth (Jalil et al., 2014). Therefore, decentralization can raise economic welfare of society as a whole. One more rationale of fiscal decentralization is that it also promotes competition among local governments and improves the quantity and quality of public goods and services (Oates, 1972, 1985).

Fiscal decentralization empowers the provincial government through financial autonomy and capacitate the central government for achieving the national tasks more effectively. It can eliminate the unnecessary engagements of central government through better targeting. Better targeting is the entering point of gender concern into fiscal decentralization process. Decentralization empowers the subnational governments in a way which help them to use the resources in a better way, improves standard of living and shares load of work (Akpan, 2011; Gordin, 2004). Transfers to provincial governments from central government ensures the better service delivery. Rise the revenue autonomy of provincial governments is essential as it is it is related with social sector's service delivery (Adam, 2007). Conversely, the opponents of fiscal decentralization claim that biased provision of social services, economic inefficiency and social inequality are caused by the decentralization (Blair, 2000; Katsiaouni, 2003; Samoff, 1990; Tanzi, 1996).

It is observed that there are many factors affected by the inequality and injustice in distribution of resources and income (Ahmad, 2013). Education is one of the factors, which is affected by such inequalities. Many important development objectives may adversely be affected by gender inequality. Less access to resources and gender inequality in education can increase the child mortality (Concepción-Zavaleta et al., 2020; Landes, 2017), fertility (Brzozowska, 2015; Samari, 2019) and an expansion of education for the next generation (El-Kogali \& Krafft, 2015). Pakistan is an underdeveloped country and there is need to improve all indicators of economic development. The Pakistani women have different status then women have in Western countries. They have weaker status in society in terms of health, education, business opportunities, employment, decision-making and legislation. There are significant gender disparities in education, across the entire country. Though, from last few decades women's equality has gained subnational attention at societal and political level. For education inequality, the government has established many educational policies in Pakistan like the national education policy in 1972, 1979, 1992 and to the achieve 100 percent literacy rate was the aim of all these policies.

The purpose of current study is to empirically investigate the impact of fiscal decentralization on gender parity/equality in education from 1975 to 2020 in Pakistan. The three objectives of the current study are to examine the effect of fiscal decentralization by using three measures i.e. expenditure decentralization, revenue decentralization and education expenditure decentralization on gender parity index of education. Local government is well informed about local gender

\footnotetext{
${ }^{1}$ In this discussion the provincial, states and sub national level of governments will be used interchangeably.
} 
educational needs so can target the gender aspect of education in a better way hence decentralization of expenditures is closely linked to gender parity. The decentralization of revenue is essential with decentralization of expenditures as it improves the performance of local government. In many ways, this study significantly departs from earlier literature. No studi has focused on gender parity in education and fiscal decentralization for the case of Pakistan in existing literature. ${ }^{2}$ Secondly, the gender parity index, used in this study, is relatively more comprehensive measure of gender parity in education. Gender parity in primary and secondary school enrolments is covered in this index. Thirdly, this study may stimulate further multidisciplinary research in public finance sector of Pakistan.

\section{Literature review}

In case of developing countries, fiscal decentralization is considered as one of the basic mechanisms to enhance the economic growth, better infrastructure and efficient public service delivery. There are numerous studies about fiscal decentralization. Different studies proved that decentralization efficiently addressed the social sector service delivery and it have significant and positive relation in various cases.

Busemeyer (2008) argued about the relationship between fiscal decentralization and public education expenditures in OECD countries. Empirical results found positive and robust relation between fiscal decentralization and education spending at aggregate level. Fiscal decentralization is linked with less spending in pension policies. Similarly, Faguet and Sánchez (2014) empirically tested the access to social services in Colombian's decentralized setup. The data covered over 95 percent of Colombian municipalities. The results proved that local democracy and political competition provides local officials more information about the needs of voters so they allocate the expenditure in such manners that their impact is maximized. The theoretical argument that decentralization improves the quality of public services held true in case of Colombia. In districts where educational policy making and financing was in local authority their school enrollment enhanced strongly. Based on these results it can be argued that the fiscal decentralization of gender policies holds good, as local governments is better informed about gender differentials, their needs and preferences.

Mehmood and Sadiq (2010) studied that how fiscal decentralization has affected human development in Pakistan by using human development index. Study used two models for two periods, annual data for 1976-2009 and panel data for 1989 to 2009 . $1^{\text {st }}$ model applied cointergration and established long run relationship while $2^{\text {nd }}$ model applied GMM on panel data to measure the effect of decentralization on human development. The result proved that fiscal decentralization increased the human development in Pakistan. However, many gender inequalities exist in Pakistan and education inequality is still high. Pakistan is moving towards decentralization of many responsibilities like health and education. Whereas, the decentralization of education responsibilities to provinces has affected the gender inequality in education or not has not explored yet. Blochliger et al. (2013) conducted a study on fiscal decentralization and its impact on economic activity, public performance and on educational system in OECD countries. Authors argued that more decentralized countries have more investments in physical and human capital. Moreover, decentralization have strongly positive relation with educational outcome and GDP per capita. Ahmed and Lodhi (2016) also found similar association between educational outcomes and fiscal decentralization in Pakistan by using time series data set and panel data set.

Sow and Razafimahefa (2015) explored the effect of fiscal decentralization on efficiency of public

\footnotetext{
${ }^{2}$ However, Stotsky, et al. (2019) examined intergovernmental fiscal transfer's effect on gender equality in education for India.
} 
service delivery and used an unbalanced penal of sixty-four developing and developed economies. The results showed that the efficiency of health and education could be improved with fiscal decentralization but under certain conditions. Firstly, the decentralization process needs sufficient institutional and political environments. Secondly, to obtain the necessary favorable outcomes, sufficient degree of expenditure decentralization is required. Thirdly, expenditure decentralization requires accompanying with necessary revenue decentralization. Without these conditions the efficiency of public service delivery in health and education can be worsen. This study lack of gender aspect of education in their analysis.

Stotsky (2019) investigated that how intergovernmental fiscal transfers affects the educational gender parity taken as enrollment at the primary and secondary levels for India. The result of the study recommended that fiscal transfers from central to states are not helpful to achieve the educational gender parity for India at aggregate level. The study also used another specification of disaggregating the transfers and grants and concluded that only unconditional fiscal transfers promotes the gender parity. While the conditional transfers have less impact on India's gender parity in education. Pakistan has many common cultural, socio-economic and political similarities. Fiscal decentralization affects female education in India but how it effects in Pakistan is still to explore.

The empirical evidences on this issue are mixed. Decentralization in education sector without proper financial and technical supports from the federal government may not be successful for the improvement in educational quality, especially for the poor. For example, Brazil has strong decentralized system in education and failed to increase the per capita education expenditure and in reducing income and regional disparities to access the educational services. The condition of the people not only worsened after decentralization in Chile, as a result, the disparities between rich and poor has increased (Carnoy, 2000).

There is an increasing trend of fiscal decentralization in Pakistan since independence. After $18^{\text {th }}$ amendment in $8^{\text {th }}$ National Finance Commission (NFC) award in 2010, the education sector is a provincial subject in Pakistan despite of this amendment, central government still make coordination and policy planning of education sector. Presently, the responsibilities of planning, monitoring and finance of basic education are given to the provincial governments (Khan \& Mirza, 2011). The fundamental aim of basic education decentralization is to improve quality and provision of basic education. Hence in the current study, it is assumed that gender parity in education can be increased with more fiscal decentralization. To the best of our knowledge, this relationship have not been empirically tested in Pakistan.

\section{Fiscal Decentralization in Pakistan}

In Pakistan, fiscal decentralization started right after independence. Several awards have been announced for resource sharing in Pakistan like The Niemeyer Award 1947, the Raisman Award 1952, and 1965 and eight NFC awards based on the 1973 Constitutions. The constitution of 1973 and all the amendments of this constitution favor more decentralized system in Pakistan than centralized system. In 1974 Zulfiqar Ali Bhutto made first attempt and established the National Finance Commission (NFC). The shares between central and provincial administrations were 80:20 respectively in $1^{\text {st }}$ NFC. Through the developmental process, in $7^{\text {th }} \mathrm{NFC}$ award shares of central and provincial governments are fixed at 56:44 respectively. This rise in the part of provincial governments permits them to expand the service delivery and distribute the funds in utmost demanding areas. In 2010, government of Pakistan undertook two significant developments. One was signing the $8^{\text {th }}$ NFC award in which bulk of resources transferred to the provinces and second was passed the $18^{\text {th }}$ Constitutional Amendment in which large range of fiscal responsibilities have been shifted to the provinces from center. These major expansions caused an essential transfer for 
the division of powers between the central and the provincial governments. Provinces now have more autonomy for macroeconomics management and delivery of public goods and services. It is generally claimed that efficiency of resource allocation is improved through fiscal decentralization.

\section{Gender Inequality in Education in Pakistan}

The vital role of education in economic growth and development has become the prominent concern for discussion and research since the 1960's. Many cultural, social, demographic and economic factors are contributing in gender disparity in education in Pakistan. The Pakistani society is patriarchal and generally women face discrimination in all sphere of life. According to the Pakistan Economic Survey, male literacy rates and enrolment rates are better than female. There is insufficient progress to decrease the gender gap in education in Pakistan. Since, independence of Pakistan, the education of female improved very steadily. There were merely 82 female secondary schools with 800 female staff and 8000 girls were enrolled of the total in Pakistan at the time of independence (50 years of Pakistan in Statistics, volume II). The education of female has remained a neglected sector over the previous 74 years and lagged much behind. As per the global gender gap report, (2020) Pakistan ranks144 number in educational attainment gap out of 156 countries as its female literacy rate is $46.5 \%$ while the male literacy rate is $71.1 \%$. This gap is particularly high in primary school enrolment where female primary school enrolment is $61.6 \%$ to $73.2 \%$ in male. According to Economic survey of Pakistan (2020) the cumulative education expenditures by federal and provincial governments stood at 1.5 percent of GDP as compared to 2.3 percent of GDP in 2019. Expenditures on education had been rising gradually until 2018-19, but in 2019-20, education-related expenditures witnessed a decrease of 29.6 percent. ${ }^{3}$ Province wise data suggests that gross enrolment ratio of female at primary level has decreased from $82 \%$ in $2014-15$ to $78 \%$ in 2019-20 in Punjab, Sindh from 69 to $62 \%$, Khyber Pakhtunkhwa from 80 to 79\%. Consequently, the economic development of the country is affected. Therefore, to pursue the broad range of critical development objective investment in female education is the most effective way.

\section{Model Specification}

The modified model to confine the relationship between fiscal decentralization and female human capital is as:

$\mathrm{EDUGEN}_{\mathrm{t}}=\mathrm{f}\left(\mathrm{FISCD}_{\mathrm{t}}, \mathrm{X}_{\mathrm{t}}\right)$

where

EDUGEN is the education gender parity index in Pakistan

FISCD is the fiscal decentralization measure

$\mathrm{X}$ consists of control variables

$\mu$ Is the error term

$t=1,2, \ldots, N$

$\beta_{0}, \beta_{1}, \beta_{2}$ and $\beta_{3}$ are parameters.

The models of expenditure decentralization, revenue decentralization and education expenditure decentralization become as:

$$
\begin{aligned}
& E_{D U G E N_{t}}=\alpha_{0}+\alpha_{1} \text { DEXP }_{t}+\alpha_{2} \text { SECEXP }_{t}+\alpha_{3} \text { FER }_{t}+\alpha_{4} F E M P_{t}+\alpha_{5} T R_{t} \\
& +\alpha_{6} \text { GDPPCG }_{t}+\mu_{i t} \\
& \text { EDUGEN }_{t}=\beta_{0}+\beta_{1} D R E V_{t}+\beta_{2} \text { SECEXP }_{t}+\beta_{3} F E R_{t}+\beta_{4} F E M P_{t}+\beta_{5} T R_{t} \\
& +\beta_{6} G D P P C G_{t}+\mu_{i t}
\end{aligned}
$$

\footnotetext{
${ }^{3}$ The education related expenditures witnessed a decline in 2020 due to closure of educational institutes amid country-wide lockdown and decrease in current expenditures (other than salaries) due to COVID-19 Pandemic.
} 


$$
\begin{aligned}
& \text { EDUGEN }_{t}=\delta_{0}+\delta_{1} E D U D_{t}+\delta_{2} \text { SECEXP }_{t}+\delta_{3} F E R_{t}+\delta_{4} F E M P_{t}+\delta_{5} T R_{t} \\
& +\delta_{6} G D P P C G_{t}+\mu_{i t}
\end{aligned}
$$

Where

- EDUGEN is the education gender parity index

- DEXP is the decentralization of expenditures

- DREV is the decentralization of revenue

- EDUD is the decentralization of education expenditures

- SECEXP is expenditure on secondary education

- FER is fertility rate

- FEMP is female labor force participation rate for ages 15-24

- TR is trade percentage of GDP

- Income is measured as GDP per capita growth rate

\section{Education Gender Parity}

The gender disparity in education is measured through several ways. However, gender differences are revealed through gross and net enrolment rates. Similarly, dropout rates and completion rates are other ways to capture the educational gender disparities. In the current study, gender parity index for gross enrollment ratio in primary and secondary education is used as measure of gender parity and it is the ratio of girls to boys enrolled at primary and secondary levels in public and private schools in Pakistan.

\section{Fiscal Decentralization Measures}

Two traditional measures of fiscal decentralization are frequently used in many studies (Cantarero \& Gonzalez, 2009; Lin \& Liu, 2000; Mehmood et al., 2010; Neyapti, 2010; Xie et al., 1999; Yilmaz, 1999; Zhang \& Zou, 1998). $1^{\text {st }}$ measure is decentralization of expenditures and calculated as the ratio of provincial government expenditures to the total government expenditures (provincials and central).

$$
D E X P=P E / P E+C E
$$

$2^{\text {nd }}$ measure is revenue decentralization it defined as the ratio of the provincial government's revenue to the total government revenue (provincials and central).

$$
D R E V=P R / P R+C R
$$

Third measure is education expenditures decentralization. Education sector is in the provincial domain after the $18^{\text {th }}$ amendment of $7^{\text {th }}$ NFC award. The composition of expenditures and social service delivery can be increased if carried out by sub-national governments (Tiebout, 1956). The ratio of provincial government education expenditures to total government education expenditures (central plus provincial) is called as education expenditures decentralization.

$$
D E D U=P E E / P E E+C E E
$$

where DEXP, PE, CE, DREV, PR, CR, DEDU, PEE and CEE are decentralization of expenditures, provincial expenditures, central government expenditures, decentralization of revenue, provincial revenue, central revenue, education expenditures decentralization, provincial education expenditures and central education expenditures respectively.

\section{Control Variables}

This study use many other control variables that are found in literature and effects the gender parity in education. To find the impact of public education policy on education, secondary school expenditures that is expressed as a percentage of total general government expenditure on education are taken. The health of female also affects her education level so total fertility rate that represents the number of children that would be born to a woman if she were to live to the end of her childbearing years is taken. A high-educated woman is more likely to have high-paid job, which 
increases the opportunity cost of childbearing and decreases the fertility. Female employment is captured as female labor force participation rate for ages 15-24 that is economically active. Trade as percentage of GDP is taken and to capture the income effect on gender parity in education GDP per capita growth as percentage of GDP is taken.

\section{Data Sources}

Annual time series data on gender parity in education and fiscal decentralization covering the period of 1975-2020 has been used in this study. Pakistan was separated from Bangladesh in 1972 so the 1975 time period is taken to see the separate impact of Pakistan Finance Commission's division of resources among provinces. Data on different measures of fiscal decentralization has been taken from various issues of Pakistan statistical year book. Data for other control variables like fertility rate, government secondary school education spending, employment of female between the age of 15-24, trade openness and GDP per-capita growth is taken from World Development Indicators published by World Bank (2020). To fill the missing values of the data, we use the linear interpolation method.

\section{The ARDL Model to Conitegration}

The autoregressive distributed lag (ARDL) cointegration technique is applied in this study to empirically analyze the long-run relationships and short-run dynamic interactions between fiscal decentralization and education gender parity index. Pesaran and Shin (1995) and Pesaran et al. (2001) developed the ARDL approach of cointegration. There are three main benefits of this approach comparing with other cointegration methods. Firstly, it is not necessary in ARDL that the entire variables must be integrated of the same order. It can be applied with variables that have mix order of integration like zero and one. Secondly, in finite and small sample data it is more efficient. Thirdly, the unbiased estimates of the long-run model can be obtained (Harris \& Sollis, 2003). The ARDL model used in this study is expressed as follows:

$$
\begin{aligned}
& \triangle E D U G E N_{t}=\beta_{1}+\beta_{2} E D U G E N_{t-1}+\beta_{3} \text { FISCD }_{i t-1}+\beta_{4} X_{i t-1}+\sum_{k=1}^{\rho} \beta_{k} \Delta E D U G E N_{i t-k} \\
& +\sum_{n=0}^{\rho} \delta_{n} \Delta X_{i t-n}+\mu_{i t}
\end{aligned}
$$

where the notation $\Delta$ indicates change in variables and all variables are previously defined.

The bounds test is based on the $F$-statistic whose null hypothesis is of no cointegration. On the basis of equation 4 , the null hypotheses for cointegration test are as follow:

$$
H_{\circ}: \beta_{1}=\beta_{2}=\beta_{3}=\beta_{4}=\beta_{5}=\beta_{6}=0
$$

It states that no cointegration exists among variables.

If null hypothesis is rejected it means variables have long-run relationship then short run relationship among variables is established through Vector Error Correction Model (VECM):

$$
\Delta \text { EDUGEN }_{\mathrm{t}}=\beta_{1}+\sum_{k=1}^{\rho} \beta_{k} \Delta E D U G E N_{i t-k}+\sum_{n=0}^{\rho} \delta_{n} \Delta X_{i t-n}+\varphi E C T_{t-1}+\mu_{i t}(6)
$$

Where one period lagged error correction term is shown through $E C T_{t-1}$. After a short run shock, the adjustment speed back to the log-run equilibrium is identified by ECM. The goodness of fit of the model is confirmed by taking diagnostic tests. The autoregressive, conditional heteroscedasticity, heteroscedasticity, sensitivity tests check the normality and serial correlation linked with the model and are presented in appendix along with descriptive statistics.

\section{Methodology \\ Unit Root test}

Before applying the ARDL bounds test, order of integration of all variables is tested. This is done to ensure that all the variables are not stationary at I (0) or at I (1). To apply the unit roots tests, 
augmented Dickey-Fuller (ADF) $(1979,1981)$ is employed for all variables used in all models and results are presented in the table 1 . The results of the stationarity tests show that some variables are stationary at level and some are stationary at first difference.

Table 1: Augmented Dickey-Fuller Unit Root Test

\begin{tabular}{lllll}
\hline Variables & $\mathbf{I}(\mathbf{0})$ & & $\mathbf{I}(\mathbf{1})$ & \\
\cline { 2 - 5 } & t-statistics & prob-value & t-statistics & prob-value \\
\hline EDUGEN & -0.279 & 0.919 & -3.357 & 0.018 \\
DEXP & -2.070 & 0.257 & -6.984 & 0.000 \\
EDUD & -2.089 & 0.249 & -5.761 & 0.000 \\
DREV & -1.923 & 0.319 & -7.319 & 0.000 \\
SECEXP & 0.404 & 0.1984 & -5.699 & 0.05 \\
FER & -4.417 & 0.001 & -0.239 & 0.925 \\
FEMP & -1.679 & 0.434 & -5.428 & 0.000 \\
TR & -2.253 & 0.191 & -6.551 & 0.000 \\
GDPPCG & -4.602 & 0.000 & -10.308 & 0.000 \\
\hline
\end{tabular}

Table 2 presents the estimated long run results of coefficients using ARDL approach and all the models are robust as various diagnostic tests have applied. Value of F-test lies above the upper bond value at $1 \%$ level for model 1 and 3 and at 10\% level for model 2 indicating existence of long run relationship among variables in all models.

Table 2 Long Run Results of the Models

\begin{tabular}{|c|c|c|c|}
\hline \multicolumn{4}{|c|}{ Dependent Variable $=$ EDUGEN } \\
\hline \multirow{4}{*}{ Variables } & Model 1 & Model 2 & Model 3 \\
\hline & $\begin{array}{l}\text { Expenditure } \\
\text { decentralization }\end{array}$ & $\begin{array}{l}\text { Education expenditure } \\
\text { decentralization }\end{array}$ & Revenue decentralization \\
\hline & F-static value $=10.209$ & F-static value $=3.559$ & F-static value $=12.262$ \\
\hline & $1 \%\left(\begin{array}{ll}3.15 & 4.43\end{array}\right)$ & $10 \%(2.123 .23)$ & $1 \%\left(\begin{array}{ll}3.15 & 4.43\end{array}\right)$ \\
\hline EDUGEN(-1) & $-0.757(0.00)$ & $-0.329(0.03)$ & $-0.660(0.00)$ \\
\hline DEXP & $0.011(0.86)$ & & \\
\hline EDUD & & $0.035(0.04)$ & \\
\hline DREV & & & $0.098(0.02)$ \\
\hline SECEXP & $-0.001(0.04)$ & $-4.182(0.88)$ & $-0.001(0.01)$ \\
\hline FER & $-0.115(0.00)$ & $-0.056(0.00)$ & $-0.101(0.00)$ \\
\hline FEMP & $-0.004(0.00)$ & $-0.001(0.16)$ & $-0.004(0.00)$ \\
\hline TR & $0.001(0.08)$ & $0.001(0.04)$ & $0.001(0.05)$ \\
\hline GDPPCG & $0.004(0.00)$ & $0.001(0.12)$ & $0.005(0.00)$ \\
\hline $\mathrm{c}$ & $1.098(0.00)$ & $0.458(0.02)$ & $0.951(0.00)$ \\
\hline
\end{tabular}

p-values are in parenthesis.

The estimated coefficient shows that expenditure decentralization remained insignificant though it has a positive impact on gender parity in education. While education expenditure decentralization 
improving the gender equality in education in Pakistan. These results are similar to the traditional theory of fiscal federalism presented by Oates (1972) and in recent literature Stotsky (2019) also found that conditional transfers from central to local governments has increased female education in India. Faguet and Sánchez (2008) found positive impact of decentralization in terms of public education outcome in Colombia. Heredia-Ortiz (2007) found positive impact of education decentralization on completion rate in developed and developing countries. Revenue decentralization also positively affect the gender equality in education in Pakistan. Iqbal et al. (2013) argued that revenue decentralization is necessary to get the desire results of fiscal decentralization. Secondary school expenditures negatively affect the gender parity in education. Education spending can affect education sector indirectly as by reducing economic growth. As Obi and Obi (2014) found not productive outcomes of public education expenditures on economic growth of Nigeria. The low level of economic growth can affect the gender equality in education. Fertility rate is also negatively affecting the gender parity in education. A number of studies has shown that female education is associated with a decrease in fertility Sackey (2005) in Ghana, Bbaale and Mpuga (2011) in Uganda, Shakya and Gubhaju (2016) in Nepal. Trade is also positively linked with reduced gender equality in education. By, Many East Asian countries are able to be competitive in global markets by adopting the strategy of women-intensive export-oriented manufacturing industries. Now many South Asia countries and developing world also following this strategy (Seguino, 2000a, 2000b). It is needed to educate the women for emergence and growth of such competitive export industries so that there may be less barriers for women employment in such sectors.

Table 3 Short Run Results of the Models

\begin{tabular}{|c|c|c|c|}
\hline \multicolumn{4}{|c|}{ Dependent Variable $=$ EDUGEN } \\
\hline \multirow{4}{*}{ Variables } & Model 1 & Model 2 & Model 3 \\
\hline & $\begin{array}{l}\text { Expenditure } \\
\text { decentralization }\end{array}$ & $\begin{array}{l}\text { Education expenditure } \\
\text { decentralization }\end{array}$ & Revenue decentralization \\
\hline & F-static value $=10.209$ & F-static value $=3.559$ & F-static value $=12.262$ \\
\hline & $1 \%(3.15 \quad 4.43)$ & $10 \%(2.123 .23)$ & $1 \%(3.15 \quad 4.43)$ \\
\hline D(EDUGEN(-1)) & $0.211(0.03)$ & $0.344(0.008)$ & $-0.660(0.00)$ \\
\hline D(EDUD) & & $-0.004(0.791)$ & \\
\hline $\mathrm{D}(\mathrm{DR}(-1))$ & & & $0.071(0.02)$ \\
\hline $\mathrm{D}(\mathrm{SECEXP})$ & $-0.001(0.04)$ & $-0.001(0.007)$ & $0.0004(0.13)$ \\
\hline D(FER(-1)) & $-0.340(0.00)$ & $-0.340(0.00)$ & $-0.355(0.95)$ \\
\hline D(FEMP(-1)) & $0.002(0.02)$ & $0.002(0.02)$ & $0.002(0.00)$ \\
\hline $\mathrm{D}(\mathrm{TR})$ & $-0.001(0.11)$ & $-0.001(0.405)$ & $0.001(0.05)$ \\
\hline D(GDPPCG(-1)) & $-0.003(0.00)$ & $-0.003(0.00)$ & $-0.004(0.00)$ \\
\hline \multirow[t]{4}{*}{$\operatorname{ECM}(-1)$} & $-0.756(0.00)$ & $-0.757(0.00)$ & $-0.582(0.00)$ \\
\hline & Adjusted R Squared= & Adjusted R Squared= & Adjusted R \\
\hline & 0.71 & 0.47 & Squared $=0.81$ \\
\hline & D.W=1.79 & $\mathrm{D} . \mathrm{W}=2.1$ & D.W=2.4 \\
\hline
\end{tabular}


p-values are in parenthesis.

Gender disparity in employment and education will decrease the ability of countries to capitalize on these plans (Busse \& Spielmann, 2006; King \& Mason, 2001). GDP per capita growth also increase the gender parity in education as nation have more financial resources to invest on gender equality in education.

The short run results are same as the long run results as the coefficient of ECM is significant at $1 \%$ level hence the result of the bounds test for cointegration is confirmed. The value of ECM is estimated to -0.756 in model $1,-0.757$ in model 2 and -0.582 in model 3 which infers a high speed of adjustment to equilibrium after any shock. In model 1 and 2 it is approximately 75 percent and in model 3 about 58 percent of disequilibria suggest that shock of the previous year converge back in one year to long run equilibrium. The stability of the long-run coefficient is tested by the short-run dynamics. After the estimation of ECM model given by equation (5), the stability of the parameters is tested by applying cumulative sum of recursive residuals (CUSUM) and the CUSUM of square (CUSUMSQ) (Pesaran and Pesaran (1997)). Graphs for CUSUM and CUSUMSQ tests for all three models are presented in appendix. The resulted plot of the CUSUM and CUSUMSQ statistic lies within the critical bands of the $5 \%$ confidence interval of parameter stability that indicate absence of any instability of the coefficients.

\section{Conclusion}

Fiscal decentralization is growing phenomenon in Pakistan and especially fiscal decentralization in education sector. It is assumed that fiscal decentralization will increase the education outcomes in Pakistan and it is also struggling to reduce the gender gaps in all spheres of life. Hence current study is based on the assumption that fiscal decentralization will increases the gender equality in education as local government has more information advantage regarding the local gender needs. To empirically investigate the long run bond between fiscal decentralization and gender parity in education, the ARDL model to cointegration is applied for the time period 1975 to 2020. The results of the study implied that decentralization of education expenditures is helpful to increase the gender parity in education in Pakistan. Revenue decentralization also increase the gender parity in education implying that it is necessary to give the sufficient revenue autonomy along with education expenditure decentralization to get the desired benefits of fiscal decentralization. Universally it is accepted that upgraded general standard of living in a society and improved citizens are created by education. Additionally, it reduces the gender gaps in many areas of life and fiscal decentralization in education is important policy tool to increase the gender equality in education in Pakistan.

\section{References}

Adam, B. E. (2007). Fiscal Decentralization and Public Service Delivery in South Africa, ATPC. Work in Progress.

Ahmad, S. (2013). Humanistic economics needed to sustain society. Indian Journal of Economics and Development, 1(4), 98-99.

Ahmed, M., \& Lodhi, A. S. (2016). Impact of fiscal decentralizations on education and healthcare outcomes: Empirical evidence from Pakistan. Journal of Applied and Emerging Sciences, 4(2), p122-134.

Akpan, E. O. (2011). Fiscal decentralization and social outcomes in Nigeria. European Journal of Business and Management, 3(4), 167-183.

Bank, W. (2020). World development indicators https://databank.worldbank.org/source/worlddevelopment-indicators

Bbaale, E., \& Mpuga, P. (2011). Female education, contraceptive use, and fertility: evidence from Uganda. Consilience(6), 20-47. 
Blair, H. (2000). Participation and accountability at the periphery: Democratic local governance in six countries. World development, 28(1), 21-39.

Brzozowska, Z. (2015). Female education and fertility under state socialism in Central and Eastern Europe. Population, 70(4), 689-725.

Busemeyer, M. R. (2008). The impact of fiscal decentralisation on education and other types of spending. Swiss Political Science Review, 14(3), 451-481.

Busse, M., \& Spielmann, C. (2006). Gender inequality and trade. Review of International Economics, 14(3), 362-379.

Cantarero, D., \& Gonzalez, P. P. (2009). Fiscal decentralization and economic growth: Evidence from Spanish regions. Public Budgeting \& Finance, 29(4), 24-44.

Carnoy, M. (2000). Globalization and educational reform. Globalization and education: Integration and contestation across cultures, 43-61.

Concepción-Zavaleta, M. J., Coronado-Arroyo, J. C., Zavaleta-Gutiérrez, F. E., \& ConcepciónUrteaga, L. A. (2020). Does level of education influence mortality of SARS-CoV-2 in a developing country? International journal of epidemiology, 49(6), 2091-2093.

El-Kogali, S., \& Krafft, C. (2015). Expanding opportunities for the next generation: Early childhood development in the Middle East and North Africa. World Bank Publications.

Faguet, J.-P., \& Sánchez, F. (2008). Decentralization's effects on educational outcomes in Bolivia and Colombia. World development, 36(7), 1294-1316.

Faguet, J.-P., \& Sánchez, F. (2014). Decentralization and access to social services in Colombia. Public choice, 160(1-2), 227-249.

Gordin, J. P. (2004). The Institutional Determinants of Fiscal Decentralisation: Argentina and Spain in Comparative Perspective. VII Congreso Español de Ciencia Política y de la Administración: Democracia y Buen Gobierno,

Harris, R., \& Sollis, R. (2003). Applied time series modelling and forecasting. Wiley.

Heredia-Ortiz, E. (2007). The impact of education decentralization on education output: A crosscountry study.

Iqbal, N., Din, M. U., \& Ghani, E. (2013). Fiscal decentralisation and economic growth: role of democratic institutions. The Pakistan Development Review, 173-195.

Jalil, A., Feridun, M., \& Sawhney, B. L. (2014). Growth effects of fiscal decentralization: Empirical evidence from China's provinces. Emerging Markets Finance and Trade, 50(4), 176-195.

Katsiaouni, O. (2003). Decentralization and poverty reduction: does it work. Paper Submitted to the Workshop on: Linking Decentralized Governance and Human Development (UNDP, UNCDF, WBI and UN-DESA) Mexico City,

Khan, A. M., \& Mirza, M. S. (2011). Implementation of Decentralization in Education in Pakistan: Framework, Status and the Way forward. Journal of Research \& Reflections in Education (JRRE), 5(2).

[Record \#624 is using a reference type undefined in this output style.]

Landes, S. D. (2017). The association between education and mortality for adults with intellectual disability. Journal of Health and Social Behavior, 58(1), 70-85.

Lin, J. Y., \& Liu, Z. (2000). Fiscal decentralization and economic growth in China. Economic Development and Cultural Change, 49(1), 1-21.

Mehmood, R., Sadiq, S., \& Khalid, M. (2010). Impact of Fiscal Decentralisation on Human Development: A Case Study of Pakistan [with Comments]. The Pakistan Development Review, 513-530.

Neyapti, B. (2010). Fiscal decentralization and deficits: International evidence. European journal of political economy, 26(2), 155-166.

Oates, W. E. (1972). Fiscal federalism. New York: Harcourt Brace Jovanovich , Inc.

Oates, W. E. (1985). Searching for Leviathan: An empirical study. The American economic review, 75(4), 748-757. 
Obi, Z. C., \& Obi, C. O. (2014). Impact of government expenditure on education: The Nigerian experience. International Journal of Business and Finance Management Research, 2(2104), 42-48.

Pesaran, M. H., \& Shin, Y. (1995). An autoregressive distributed lag modelling approach to cointegration analysis.

Pesaran, M. H., Shin, Y., \& Smith, R. J. (2001). Bounds testing approaches to the analysis of level relationships. Journal of applied econometrics, 16(3), 289-326.

[Record \#619 is using a reference type undefined in this output style.]

Samari, G. (2019). Education and fertility in Egypt: Mediation by women's empowerment. SSMpopulation health, 9, 100488.

Samoff, J. (1990). Decentralization: The politics of interventionism. Development and Change, 21(3), 513-530.

Seguino, S. (2000a). Accounting for gender in Asian economic growth. Feminist Economics, 6(3), 27-58.

Seguino, S. (2000b). Gender inequality and economic growth: A cross-country analysis. World development, 28(7), 1211-1230.

Shakya, K., \& Gubhaju, B. (2016). Factors contributing to fertility decline in Nepal. Journal of Population and Social Studies [JPSS], 24(1), 13-29.

Sow, M., \& Razafimahefa, M. I. F. (2015). Fiscal decentralization and the efficiency of public service delivery. International Monetary Fund.

Stotsky, J. G. S., J.G. \& Piyush, G. . (2019). Impact of intergovernmental fiscal transfers on gender equality in India: an empirical analysis. [Working Paper 1/2019]. Tax and Transfer Policy Institute. (Australian National University.)

Tanzi, V. (1996). Fiscal federalism and decentralization: A review of some efficiency and international bank for reconstruction and development. The World Bank.

Tiebout, C. M. (1956). A pure theory of local expenditures. Journal of political Economy, 64(5), 416-424.

Xie, D., Zou, H.-f., \& Davoodi, H. (1999). Fiscal decentralization and economic growth in the United States. Journal of Urban Economics, 45(2), 228-239.

Yilmaz, S. (1999). The impact of fiscal decentralization on macroeconomic performance. Proceedings. Annual Conference on Taxation and Minutes of the Annual Meeting of the National Tax Association,

Zhang, T., \& Zou, H.-f. (1998). Fiscal decentralization, public spending, and economic growth in China. Journal of public economics, 67(2), 221-240.

Appendix

Descriptive statistics

\begin{tabular}{lllll}
\hline Variables & Mean & Std. Dev. & Min & Max \\
\hline EDUGEN & .639 & .160 & .396 & .879 \\
DEXP & .291 & .031 & .246 & .372 \\
EDUD & .818 & .142 & .363 & .975 \\
DREV & .297 & .041 & .193 & .3821 \\
SECEXP & 31.871 & 7.482 & 24.411 & 57.448 \\
FER & 5.204 & 1.152 & 3.454 & 6.612 \\
FEMP & 13.516 & 4.459 & 5.92 & 20.65 \\
TR & 32.154 & 3.555 & 25.306 & 38.499 \\
GDPPCG & 2.006 & 1.901 & -1.843 & 6.695 \\
\hline \multicolumn{5}{c}{ Diagnostic tests } \\
\hline Model 1 & Model 2 & Model 3 \\
Expenditure decentralization & Education \\
& decentralization \\
\hline
\end{tabular}




\begin{tabular}{|c|c|c|c|c|c|}
\hline $\begin{array}{l}\text { Breusch-Godfrey } \\
\text { Correlation test } \\
\chi 2 \text { statistic }=0.19(0.82)\end{array}$ & Serial & $\begin{array}{l}\text { Breusch-Godfrey } \\
\text { Correlation test } \\
\chi^{2} \text { statistic }=1.72(0.19)\end{array}$ & Serial & $\begin{array}{l}\text { Breusch-Godfrey } \\
\text { Correlation test } \\
\chi 2 \text { statistic }=0.29(0.75)\end{array}$ & Se \\
\hline $\begin{array}{l}\text { era test } \\
\mathrm{ic}=1.21(0.55)\end{array}$ & & $\begin{array}{l}\text { ra test } \\
c=2.16(0.34)\end{array}$ & & $\begin{array}{l}\text { ra test } \\
c=2.77(0.25)\end{array}$ & \\
\hline $\begin{array}{l}\text { Ramsey RESET Test } \\
\text { likelihood ratio) } \\
\chi 2 \text { statistic }=2.33(0.12)\end{array}$ & & $\begin{array}{l}\text { Ramsey RESET Test } \\
\text { likelihood ratio) } \\
\chi 2 \text { statistic }=0.23(0.79)\end{array}$ & & $\begin{array}{l}\text { Ramsey RESET Test } \\
\text { likelihood ratio) } \\
\chi 2 \text { statistic }=2.44(0.10)\end{array}$ & \\
\hline
\end{tabular}

\begin{tabular}{ccccccc}
\hline \multicolumn{7}{c}{ Lag length selection of model 1 } \\
\hline Lag & LogL & LR & FPE & AIC & SC & HQ \\
\hline 0 & -244.4919 & NA & 0.000284 & 11.69730 & 11.98401 & 11.80303 \\
1 & 39.88506 & 462.9393 & $5.15 \mathrm{e}-09$ & 0.749532 & 3.043188 & 1.595362 \\
2 & 140.5070 & 131.0425 & $5.60 \mathrm{e}-10$ & -1.651488 & $2.649117^{*}$ & -0.065558 \\
3 & 225.3691 & $82.88856^{*}$ & $1.80 \mathrm{e}-10^{*}$ & $-3.319493^{*}$ & 2.988061 & $-0.993462^{*}$ \\
\hline \multicolumn{7}{c}{ Lag length selection of model 2 } \\
\hline Lag & LogL & LR & FPE & AIC & SC & HQ \\
\hline 0 & -334.0013 & NA & 0.012714 & 15.50006 & 15.78391 & 15.60533 \\
1 & -23.36446 & 508.3149 & $8.95 e-08$ & 3.607475 & 5.878262 & 4.449593 \\
2 & 73.40270 & $127.5567^{*}$ & $1.21 \mathrm{e}-08^{*}$ & $1.436241^{*}$ & $5.693966^{*}$ & $3.015211^{*}$ \\
\hline \multicolumn{7}{c}{ Lag length selection of model 3 } \\
\hline Lag & LogL & LR & FPE & AIC & SC & HQ \\
\hline 0 & -255.0580 & NA & 0.000464 & 12.18875 & 12.47545 & 12.29447 \\
1 & 21.07575 & 449.5201 & $1.23 \mathrm{e}-08$ & 1.624384 & 3.918040 & 2.470213 \\
2 & 127.4616 & $138.5490^{*}$ & $1.03 \mathrm{e}-09$ & -1.044724 & $3.255881^{*}$ & $0.541206^{*}$ \\
3 & 191.4576 & 62.50776 & $8.71 \mathrm{e}-10^{*}$ & $-1.742214^{*}$ & 4.565340 & 0.583817 \\
\hline
\end{tabular}

* indicates lag order selected by the criterion

LR: sequential modified LR test statistic (each test at 5\% level)

FPE: Final prediction error

AIC: Akaike information criterion

SC: Schwarz information criterion

HQ: Hannan-Quinn information criterion

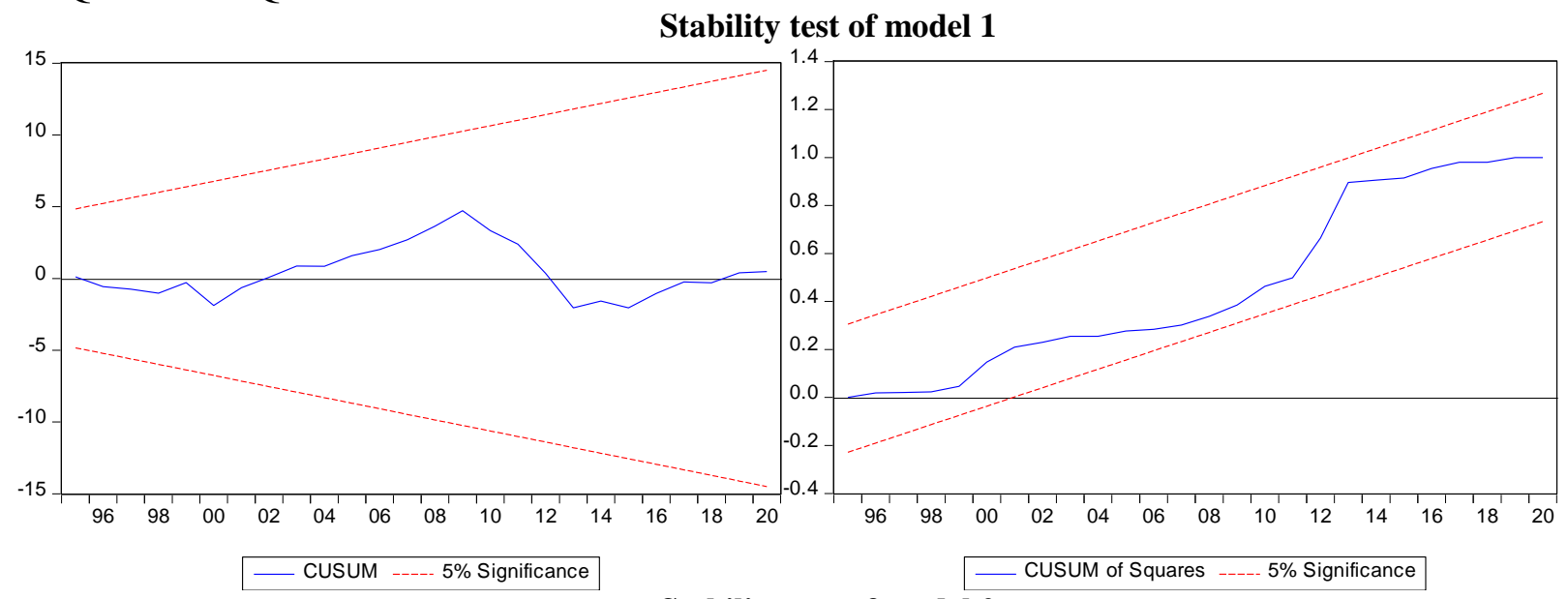

Stability test of model 2 

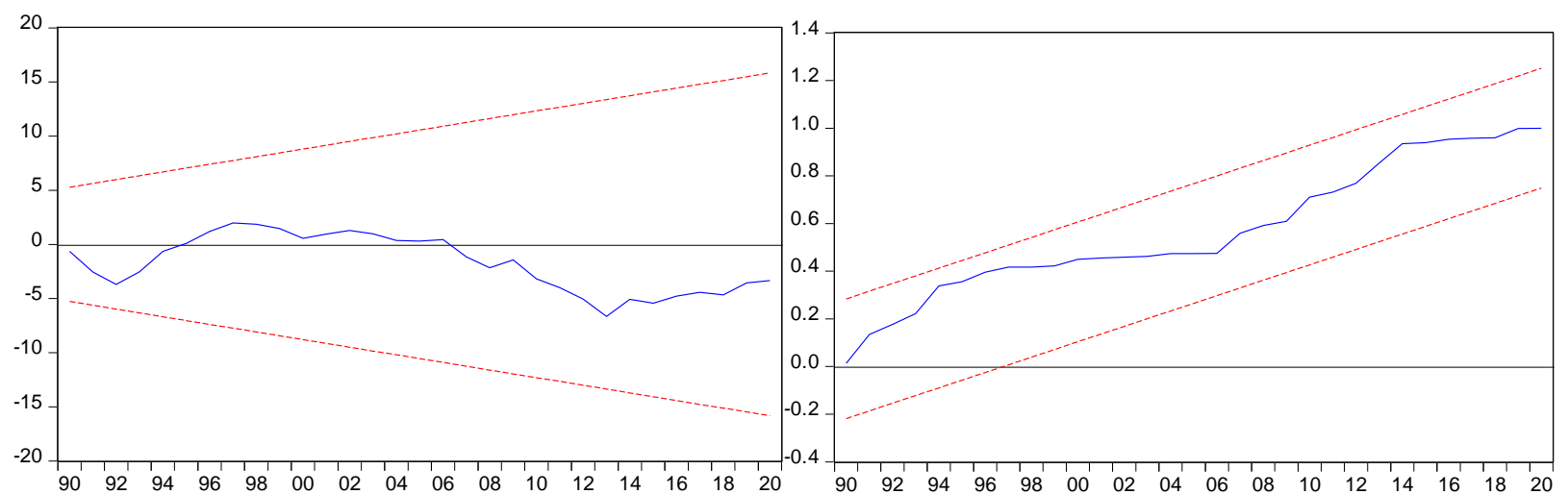

_ CUSUM ---- 5\% Significance

Stability test of model 3
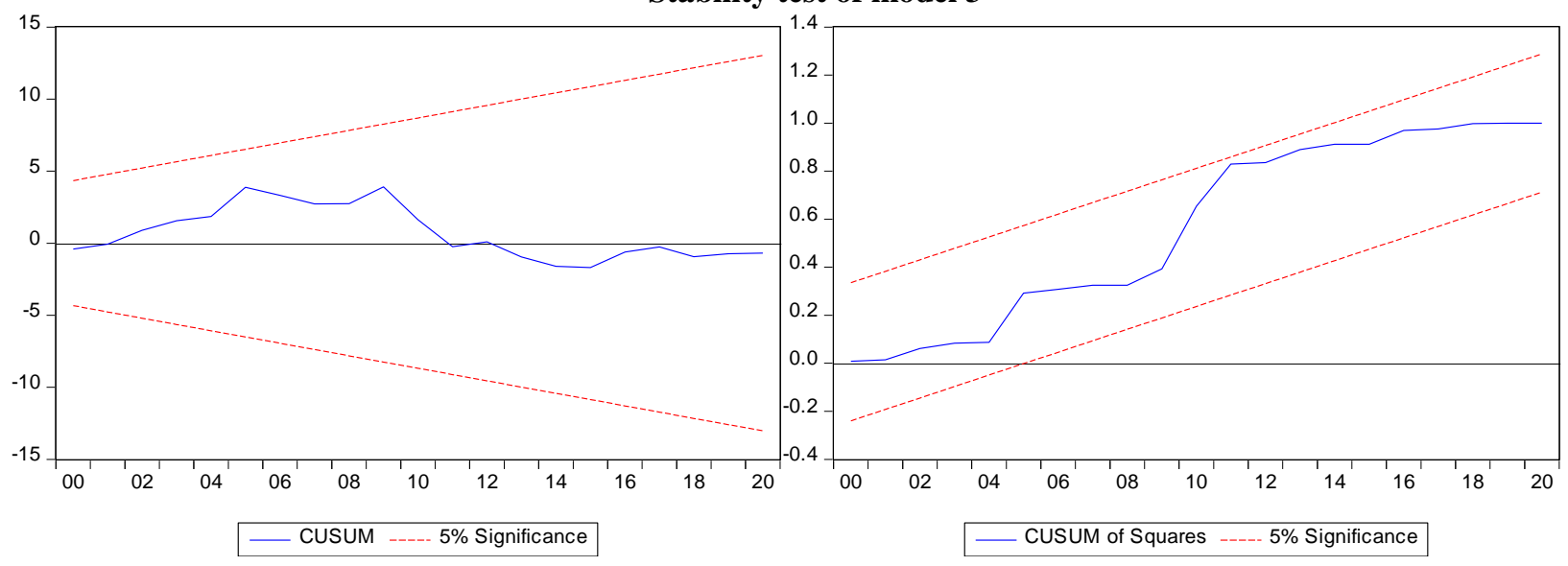